\title{
Government Guarantees and Self-Fulfilling Speculative Attacks*
}

\author{
Craig Burnsideł Martin Eichenbaumand Sergio Rebelo ${ }^{\S}$
}

March 2003

\begin{abstract}
This paper explores the role played by government guarantees to banks' foreign creditors as a root cause of self-fulfilling twin banking-currency crises. We develop a general equilibrium model in which such guarantees lead to these types of crises. Absent government guarantees, such crises are not possible. The model has three key properties. First, in the presence of government guarantees banks willingly expose themselves to exchange rate risk: they borrow foreign currency, lend domestic currency and do not hedge the resulting exchange rate risk. In effect this provides a theory of debt denomination that rationalizes a key maintained assumption of the recent literature on currency crises: banks are exposed to unhedged currency risk. Second, banks renege on their foreign debts and declare bankruptcy when a devaluation occurs. Third, the government is either unable or unwilling to fully fund the costs associated with bank guarantees via an explicit fiscal reform. Taken together these three properties imply that government guarantees lead to self-fulfilling banking-currency crises.
\end{abstract}

J.E.L. Classification: F31, F41, G15, G21.

Keywords: Fixed exchange rate regimes, hedging, government guarantees, debt denomination.

*This paper was previously circulated under the title "On the Fundamentals of Self-Fulfilling Speculative Attacks". We gratefully acknowledge grants from the National Science Foundation through the N.B.E.R. and financial support from Kellogg's Banking Research Center. Burnside thanks the Hoover Institution for its support through a National Fellowship. The opinions in this paper are those of the authors and not necessarily those of the Federal Reserve Bank of Chicago or the World Bank. We are thankful to Larry Christiano and Olivier Jeanne for their comments.

†The World Bank.

${ }^{\ddagger}$ Northwestern University, NBER and Federal Reserve Bank of Chicago.

$\S$ Northwestern University, NBER and CEPR. 


\section{Introduction}

The past decade has witnessed dramatic collapses of fixed exchange rate regimes in countries as diverse as Sweden, Mexico and Thailand. While there is disagreement about the causes of these crises, there is widespread agreement that currency crises have become increasingly linked to banking crises. This is the 'twin crises' phenomenon emphasized by Kaminsky and Reinhart (1999). This paper explores the role played by government guarantees to banks' foreign creditors as a root cause of such crises. ${ }^{1}$ The key channel that we emphasize is the impact of government guarantees on the currency composition of banks' assets and liabilities. We develop a simple general equilibrium model in which the optimal response of banks to government guarantees is to adopt currency risk. This response opens the door to self-fulfilling twin banking-currency crises.

Our model has three key properties. First, in the presence of government guarantees banks willingly expose themselves to exchange rate risk: they borrow foreign currency, lend domestic currency and do not hedge the resulting exchange rate risk. In effect this provides a theory of debt denomination that rationalizes a key maintained assumption of the recent literature on currency crises: banks are exposed to unhedged currency risk. ${ }^{2}$ Second, banks find it optimal to renege on their foreign debts and declare bankruptcy when a devaluation occurs. Consequently, a devaluation transforms potential government liabilities into actual liabilities. Third, the government is either unable or unwilling to fully fund the costs associated with bank guarantees via a fiscal reform. ${ }^{3}$ Therefore it must raise seigniorage revenues. Taken together these three properties imply that government guarantees lead to self-fulfilling banking-currency crises. Absent government guarantees, such crises are not possible.

The basic intuition for our results can be summarized as follows. Consider a situation in which (i) the government offers guarantees to banks' foreign creditors and (ii) there is a limit on the amount of reserves that the government is willing to lose in defense of the fixed exchange rate. The guarantees can be thought of as an option that is valuable to

\footnotetext{
${ }^{1}$ Mishkin (1996) and Obstfeld (1998) argue that a government's promise to maintain a fixed exchange rate is often seen as providing an implicit guarantee to banks' creditors against the effects of a possible devaluation.

${ }^{2}$ See for example, Chang and Velasco (2000), and Krugman (1999), and Eichengreen and Hausmann (2000).

${ }^{3}$ We abstract from negative output effects following a currency crisis. Other things equal, a post-crisis recession would reduce the real value of the government's tax revenues. This would exacerbate the fiscal implications of the crisis. Incorporating these effects into our model would make it easier to generate selffulfilling currency crises.
} 
banks only if they have an unhedged currency mismatch between their assets and liabilities. This is why banks are willing to borrow foreign currency and lend domestic currency. Now suppose that private agents believe that a devaluation is imminent and that the government will finance bank bailouts, at least in part, via seigniorage revenues. Then these agents will exchange domestic money for foreign reserves to the point where the fixed exchange rate regime is abandoned. In the resulting devaluation, banks declare bankruptcy which activates the government's obligations to foreign creditors. As a consequence, the government will validate agents' expectations by partially financing the bailout with seigniorage revenues. Thus government guarantees trigger a self-fulfilling, rational run on the domestic currency, a devaluation and a banking crisis. Paradoxically, government guarantees make banks and the economy less stable, not more stable. This is consistent with the evidence provided by Demirgüç-Kunt and Detragiache (2000) that government guarantees are detrimental to bank stability.

To simplify the analysis we assume, in our benchmark model, that banks finance themselves entirely by borrowing abroad in dollars. In reality, local currency borrowing is an important form of bank financing. So our benchmark model overstates the currency mismatch between banks' assets and liabilities. Because of this we extend the model to allow for domestic deposits. We then show that under guarantees banks use forward markets to attain the same level of currency exposure that they had in the absence of domestic deposits. As a consequence the main results for the benchmark model also hold for the extended model.

How can the government prevent self-fulfilling twin crises? The most obvious strategy is to (somehow) credibly commit to financing post-devaluation bank bailouts without recourse to seigniorage revenues. Given the difficulty of implementing this strategy, we discuss five other possibilities. The first is related to a recent proposal by Feldstein (1999): the government must obtain and be willing to use a 'sufficient' amount of reserves to fend off a speculative attack. A second strategy is to impose state-contingent Tobin tax on exchange rate transactions. A third strategy is to impose capital requirements on the banks. The fourth is to dollarize the economy. The fifth is get to someone else to pay for the bank bailouts.

It is useful to contrast the central idea pursued in this paper to other work on banking and currency crises. Various authors have emphasized the interaction between government 
guarantees and adverse real shocks in generating financial crises. ${ }^{4}$ The real shocks in Velasco (1987) and in Corsetti, Pesenti and Roubini (1999) are declines in output or productivity. ${ }^{5}$ In Dooley's (2000) analysis the shock is an increase in international reserves that allows the government to set up a credible deposit insurance scheme. ${ }^{6}$ In a different vein, McKinnon and Pill $(1996,1998)$ argue that, when banks have an information advantage about the returns to domestic investments, government guarantees can lead to over-borrowing on the part of the private sector and twin crises. Chinn and Kletzer (2000) stress the link between agency problems in the financial intermediation process and banking-currency crises. ${ }^{7}$

Like the papers cited above, we focus on the role played by government guarantees. But we emphasize a very different channel by which guarantees can generate twin crises: they make it optimal for banks to have a currency mismatch between their assets and liabilities. ${ }^{8}$ This mismatch leads to the possibility of self-fulfilling speculative attacks which emphasizes the inherent fragility of fixed exchange rates under government guarantees. In contrast, in all of the papers cited above a collapse of the fixed exchange rate regime is inevitable. In our model a currency crisis does not occur if agents believe that the fixed exchange rate regime is sustainable. But if agents believe that a devaluation will take place, then their actions imply that it will.

Finally, we note that at least three other papers in the literature discuss models in which a currency mismatch is associated with self-fulfilling currency crises. In Aghion, Bacchetta and Banerjee (2001a,b) firms have limited liability and the currency composition of their portfolio is not observable. As a result it can be optimal for firms to borrow in foreign currency against sales of products that are priced in local currency. If prices are sticky,

\footnotetext{
${ }^{4}$ Diaz-Alejandro (1985) provides an early discussion of the role of government guarantees in financial crises.

${ }^{5}$ Banks (in Velasco (1987)) and firms (in Corsetti et al (1999)) respond to these shocks by embarking on Ponzi-like schemes where they borrow from abroad at the risk-free rate. They are able to do so because of government guarantees. Eventually, the foreign debt accumulated by banks and firms reaches an exogenous upper bound. At this point a financial crisis ensues and the government becomes responsible for the foreign debt of banks and firms.

${ }^{6}$ In Dooley's model once this scheme is in place, new deposits arrive over time and are embezzled by the banks. Agents are willing to deposit new funds until the banks' insured losses equal the size of the government's insurance fund. At that point there is a bank run that activates the government guarantees.

${ }^{7}$ There is also a strand of the literature that extends the Diamond-Dybvig bank run model to an open economy context. See Chang and Velasco (2000) for a survey.

${ }^{8}$ Burnside, Eichenbaum and Rebelo (2001) also study banks' hedging strategies in fixed exchange rate regimes. However, a crucial assumption in that paper is that exchange rates follow an exogenous stochastic process. So that paper cannot address the possibility of self-fulfilling currency crises or study policies that prevent such crises.
} 
a devaluation lowers firms' profits. In the presence of credit constraints this reduces the borrowing capacity of firms. This in turn leads to decline in investment and output which lowers the demand for domestic currency, thus leading to a self-fulfilling currency crisis.

Schneider and Tornell (2000) consider a model with two frictions. First, there is imperfect contract enforceability in loan markets. Second, there are bailout guarantees so that lenders receive a fraction of the outstanding debt of all defaulting entrepreneurs, regardless of debt denomination. This bailout, which is granted by an international organization, results in a windfall gain for the country. The interplay between these two friction can induce nontradable good firms to acquire more risk by borrowing in foreign currency. This can generate a self-fulfilling currency crisis because a real depreciation leads, through balance sheet effects, to a drop in the demand for nontradables which validates the real depreciation.

While these models emphasize the role of credit market frictions, our paper shows that these are not necessary to explain currency mismatches and self-fulfilling currency crises. In our model government guarantees to banks are sufficient to generate both phenomena.

The remainder of this paper is organized as follows. Section 2 presents a model of a small open economy which is populated by four different sets of agents: banks, firms, households, and a government. Banks are modeled in the tradition of Kareken and Wallace (1978). Specifically, we abstract from the role of banks as producers of information and concentrate on their role as producers of loans. This allows us to focus on the interaction of government guarantees and exchange rate risk in a relatively simple environment.

In our analysis, banks borrow dollars from abroad and make domestic currency loans to firms. This currency mismatch exposes banks to foreign exchange rate risk which can be hedged in forward currency markets. We characterize banks' optimal hedging strategy when the government guarantees that foreign creditors will be repaid in the event of a devaluation. In addition we consider the case with no guarantees. Firms borrow funds to hire labor and produce output using a constant returns to scale technology. Households supply labor inelastically and derive utility from consumption and domestic real balances. Because they have access to international capital markets they have a nontrivial forward-looking portfolio problem. In particular, the amount of domestic real balances that they hold depends on their beliefs about the longevity of the fixed exchange rate regime. The government faces an intertemporal budget constraint which must hold for every realization of the state of the economy. To simplify the analysis we assume, as in Krugman (1979), that the government 
follows a threshold rule according to which it abandons the fixed exchange rate regime when its reserve losses reach a critical level.

Section 3 discusses the competitive equilibrium when self-fulfilling speculative attacks are ruled out by assumption. Section 4 analyzes the conditions under which these attacks can occur. Section 5 extends the benchmark model to allow for domestic deposits. Section 6 discusses policy options. Section 7 concludes.

\section{The Basic Model}

We consider a simple general equilibrium model of a small open economy. By assumption there is a single consumption good and no barriers to trade, so that purchasing power parity holds:

$$
P_{t}=S_{t} P_{t}^{*}
$$

Here $P_{t}$ and $P_{t}^{*}$ denote the domestic and foreign price level respectively, while $S_{t}$ denotes the exchange rate defined as units of domestic currency per unit of foreign currency. For convenience we normalize the foreign price level to one: $P_{t}^{*}=1$ for all $t$.

The economy is initially in a fixed exchange rate regime with $S_{t}=S^{I}$. To allow for the possibility of a self-fulfilling speculative attack, we suppose that agents coordinate on some signal, observed at the beginning of each period. The signal takes on the values zero or one with probabilities $1-q$ and $q$, respectively. When the signal is equal to zero, agents believe that the fixed exchange rate will endure for at least one more period. If the signal equals one, then agents believe the fixed exchange rate regime will collapse before the end of the period, with the exchange rate initially depreciating to an endogenously determined value $S^{D}$ and then depreciating at the rate $\gamma$ per unit of time.

The key question is whether agents' beliefs about a devaluation can be self-fulfilling. We denote by $T$ the random time of a (possible) self-fulfilling speculative attack. It is useful to distinguish between three types of time periods in the life of our model economy.

- Fixed Exchange Rate Regime: here $S_{t}=S^{I}$ for all $t<T$ and the supply of money is determined by the central bank's need to fix the nominal exchange rate.

- Devaluation Period: this is the time period $T$ in which the fixed exchange rate is abandoned. To simplify our analysis, we adopt the standard assumption of the speculative 
attack literature regarding the behavior of the monetary authority. ${ }^{9}$ Specifically, we assume that the central bank defends the fixed exchange rate $S^{I}$ by selling its reserves at that price until reserves fall by an amount $\chi$. Once this happens, the central bank floats the exchange rate, and allows the money supply to grow at the rate $\gamma$ forever.

- Floating Exchange Rate Regime: this obtains for all $t>T$. The growth rate of money is equal to $\gamma$. We consider two separate cases. In the first case the government does not change its tax and spending policy in the aftermath of the devaluation. Here $\gamma$ is endogenously determined by the magnitude of the bank bailout and the government's intertemporal budget constraint. In the second case $\gamma$ is given exogenously and taxes adjust so that the government's intertemporal budget constraint holds.

The economy is populated by four sets of agents: perfectly competitive banks, goods producing firms, households, and a government. In the following subsection we provide a detailed analysis of the banking sector. We then discuss the problems of the other agents in the economy.

\subsection{The Banking Sector}

In this subsection we analyze a simplified version of the banking model in Burnside, Eichenbaum and Rebelo (2001). We begin by assuming that banks borrow in dollars and lend in local currency, so they are exposed to exchange rate risk. Later we show that, in the presence of guarantees, banks are willing to take on this currency mismatch.

The focus of our analysis is on banks' optimal hedging strategies when the economy is operating under the fixed exchange rate regime discussed above, i.e. at time $t<T$. We show that: (i) it is optimal for a bank to fully hedge exchange rate risk when there are no government guarantees to foreign creditors; and (ii) it is not optimal for a bank to hedge exchange rate risk in the presence of government guarantees. With guarantees, it is optimal for banks to declare bankruptcy when the currency is devalued. The optimal hedging strategy has the property that, when a bank declares bankruptcy, its residual value net of bankruptcy costs is zero.

We assume that banks are perfectly competitive and their actions are publicly observable. Individual banks borrow foreign currency at a gross interest rate $R^{b}$, and they lend to domestic firms in local currency at a fixed gross interest rate $R^{a}$. When firms repay their

\footnotetext{
${ }^{9}$ See, for example, Krugman (1979), Flood and Garber (1984), and Lahiri and Vegh (1999).
} 
loans, the exchange rate $S$ is either $S^{I}$, if the fixed exchange rate regime is sustained, or $S^{D}$ if a devaluation has occurred.

To simplify the analysis we assume, for now, that banks do not borrow funds from domestic residents. Instead, banks finance themselves entirely by borrowing $L$ dollars in the international capital market. These funds are converted into units of local currency at the prevailing exchange rate, $S^{I}$. In Section 5 we extend the model to allow banks to borrow funds from local residents. While this extension enriches the model, it does not affect our basic results.

An important objective of our analysis is to explore why banks do not hedge their exchange rate risk. We adopt assumptions about forward markets that make hedging exchange rate risk as attractive as possible. In particular, we assume that forward contracts are priced by risk-neutral agents and traded in frictionless markets. ${ }^{10}$

Perfect forward markets are an interesting benchmark case for at least three reasons. First, they allows us to analyze what would happen if all forward market imperfections were eliminated. Our analysis implies that banks would not avail themselves of these markets in the presence of government guarantees. Second, twin crises don't happen only in developing economies where forward markets may well be imperfect. They also occur in countries such as Sweden and Finland where the assumption of well-functioning forward markets seems reasonable. Finally, the benchmark case makes clear one reason why forward markets may not exist: in fixed exchange rate economies with government guarantees, banks have no incentive to participate in them.

We denote by $F$ the one-period forward exchange rate defined as units of local currency per dollar. Under our assumptions $F$ is given by:

$$
\frac{1}{F}=(1-q) \frac{1}{S^{I}}+q \frac{1}{S^{D}}
$$

This condition states that the expected real rate of return of purchasing a forward contract, denominated in units of the consumption good, is equal to zero.

Relation (2.2) implies that forward contracts make a profit in the devaluation state since $S^{D}>S^{I}$. To lend $L$ dollars, banks must incur transactions costs of $\delta L$. This cost introduces

\footnotetext{
${ }^{10}$ See Burnside, Eichenbaum and Rebelo (2001) for evidence that there was a variety of vehicles available to at least partially hedge exchange rate risk in many of the twin-crises countries.
} 
a bid-ask spread in interest rates. Dollar-denominated profits from these loans are:

$$
\pi^{L}(S)=\frac{R^{a} S^{I} L}{S}-R^{b} L-\delta L
$$

Dollar-denominated profits from hedging activities are given by:

$$
\pi^{H}(S)=x\left(\frac{1}{F}-\frac{1}{S}\right) .
$$

Here $x$ denotes the number of units of local currency sold by the bank in the forward market. We assume that there is full information about the values of $L$ and $x$ chosen by the banks. The expected value of the bank's profits from hedging is $E\left(\pi^{H}\right)=0$. Total dollar-denominated profits, $\pi$, are given by

$$
\pi(S)=\pi^{L}(S)+\pi^{H}(S)
$$

Banks can default on loans contracted in the international capital market. Note that, since banks live for one period, it is optimal for them to default whenever their total profits are negative. When a bank defaults, it has gross assets with a residual value given by

$$
V^{R}(S)=\frac{R^{a} S^{I} L}{S}-\delta L+x\left(\frac{1}{F}-\frac{1}{S}\right) .
$$

These assets, net of bankruptcy costs, are distributed to the bank's international creditors. We assume that bankruptcy costs are given by $\omega L$, where $\omega>0$. We think of $\omega L$ as representing the direct costs of bankruptcy, including the associated legal, accounting and administrative costs. ${ }^{11}$ These bankruptcy costs do not apply to forward contracts. This is because we assume that there is no default on forward markets, since contracts must be settled before the bank's foreign creditors are paid. If there were substantial defaults associated with forward contracts, prices would vary significantly across firms. In reality, this does not seem to be the case because forward contracts are heavily collateralized. ${ }^{12}$

The no-default condition on forward contracts implies that, if the bank defaults, its residual value inclusive of any profits or losses in forward markets, must be sufficiently large to pay its bankruptcy costs: $V^{R}(S) \geq \omega L$ for all $(x, L)$ such that $V^{R}(S)<R^{b} L$. Using $(2.5)$ this condition can be written as

$$
\frac{R^{a} S^{I} L}{S}-\delta L+x\left(\frac{1}{F}-\frac{1}{S}\right) \geq \omega L
$$

\footnotetext{
${ }^{11}$ See Betker (1997) for a discussion of these costs and for an estimate of their magnitude in the US.

${ }^{12}$ See Sercu and Uppal (1995), Chapter 4.
} 
For a given value of $L$, this imposes finite upper and lower bounds on the value of $x$ that an individual bank can choose.

It is optimal for banks to default in states of the world where $\pi$ is negative. The expected profit of a bank that defaults whenever $\pi(S)<0$ is

$$
V=(1-q) \max \left\{\pi\left(S^{I}\right), 0\right\}+q \max \left\{\pi\left(S^{D}\right), 0\right\}
$$

In the Appendix we show that the bank's expected profit can be expressed as:

$$
V=\left(\frac{S^{I}}{F} R^{a}-\delta\right) L-E C B(x, L)
$$

where $E C B$, the expected cost of borrowing, is given by,

$$
E C B(x, L)=\operatorname{Pr}(\text { no default }) \times R^{b} L+\operatorname{Pr}(\text { default }) \times V^{R} .
$$

In equation (2.8), $x$ only affects $\operatorname{ECB}(x, L)$. So, for any given $L$, it is optimal for a bank to choose $x$ in order to minimize $\operatorname{ECB}(x, L)$.

We consider two scenarios. In the first scenario there are no government guarantees to foreign creditors. If banks default foreign creditors receive the residual value of the bank net of bankruptcy costs, $V^{R}-\omega L$. In the second scenario the government guarantees foreign creditors against default by domestic banks in the event of a devaluation, up to a repayment limit of $R L$. Here $R$ denotes the exogenously given risk free interest rate in international capital markets. ${ }^{13}$

\section{No Government Guarantees}

Absent government guarantees, $R^{b}$ is determined by the condition that the expected return to international creditors equals $R$ :

$$
R L=\operatorname{Pr}(\text { no default }) \times R^{b} L+\operatorname{Pr}(\text { default }) \times\left(V^{R}-\omega L\right)
$$

We now state a simple result that summarizes banks' optimal hedging behavior in an economy with no government guarantees.

\footnotetext{
${ }^{13}$ Working in a setting where the probability of a devaluation is exogenous, Burnside, Eichenbaum and Rebelo (2001) analyze the case in which government guarantees are not conditioned on devaluations and show that bankruptcies can occur even absent devaluations. In addition they show that the model can be easily extended to accommodate the case in which there are partial or probabilistic guarantees.
} 
Proposition 1 In an economy with no guarantees and $\omega>0$, it is optimal for banks to fully hedge exchange rate risk. When $\omega=0$, the Modigliani-Miller theorem applies and the banks are indifferent between hedging and not hedging.

Proof: See the Appendix.

To see the basic intuition behind this proposition note that using (2.9), we can write (2.10) as:

$$
R L=E C B(x, L)-\operatorname{Pr}(\text { default }) \times \omega L,
$$

so that

$$
E C B(x, L)=R L+\operatorname{Pr}(\text { default }) \times \omega L .
$$

Banks can avoid paying bankruptcy costs by choosing $x$ so that $\pi(S) \geq 0$ for all $S$. This strategy is optimal because it minimizes $\operatorname{ECB}(x, L)$. This establishes that in the absence of government guarantees, banks will be fully hedged and will never go bankrupt.

For future reference, it is useful to note that given a full hedging strategy, the bank's first order condition for $L$ is:

$$
\frac{R^{a} S^{I}}{F}=R+\delta .
$$

This expression equates the expected real return to lending to the real cost of borrowing $(R)$ plus the marginal cost of producing a loan $(\delta)$.

\section{Government Guarantees}

In the presence of government guarantees $R^{b}$ is given by:

$$
\begin{gathered}
R L=\operatorname{Pr}(\text { no default }) \times R^{b} L+\operatorname{Pr}\left(\text { default when } S=S^{I}\right) \times\left(V^{R}-\omega L\right)+ \\
\operatorname{Pr}\left(\text { default when } S=S^{D}\right) \times \max \left\{V^{R}-\omega L, R L\right\}
\end{gathered}
$$

Proposition 2 In an economy where the government guarantees to repay banks' foreign debt in the event of a devaluation and $\omega<R$, it is not optimal for banks to fully hedge exchange rate risk. Their optimal strategy is to set $x$ to its lowest permissible value. Proof: See the Appendix.

The intuition underlying Proposition 2 can be seen as follows. A bank whose $(x, L)$ is such that it defaults only in the devaluation state $\left(S=S^{D}\right)$, can borrow at the risk free rate: $R^{b}=R$. This fact and (2.9) imply that

$$
\operatorname{ECB}(x, L)=(1-q) R L+q V^{R}\left(S^{D}\right) .
$$


Consider a bank that decided to default in the devaluation state. Its optimal strategy is to choose $x$ to minimize $E C B(x, L)$, defined in (2.13). This requires setting $x$ to its lowest feasible value so that $V^{R}\left(S^{D}\right)=\omega L$. It follows that when the bank pursues this strategy,

$$
E C B(x, L)=(1-q) R L+q \omega L
$$

In contrast, suppose that the bank chooses a hedging strategy such that it is never optimal to default. Then $R^{b}=R$, and

$$
E C B(x, L)=R L
$$

As long as $q$ is positive and $\omega<R$, the optimal strategy for a bank is the first one, namely set $x$ to its lowest feasible bound and default whenever the devaluation state occurs. Following an argument similar to that used in the proof of Proposition 1, one can show that it is not optimal to default in the no-devaluation state, since government guarantees do not apply in that state.

The optimal value of $x$ can be negative, so that banks make hedging profits during the fixed exchange rate regime and lose money when the currency is devalued. A negative $x$ allows banks to minimize their residual value in bankruptcy states, so that $V^{R}\left(S^{D}\right)=\omega L$. As a consequence, there are no assets, after bankruptcy costs, for the government to seize in order to offset their liabilities to banks' foreign creditors.

It is useful to note, for future reference, that given the banks' optimal hedging strategy when there are government guarantees, its first order condition for $L$ is:

$$
\frac{R^{a} S^{I}}{F}=(1-q) R+\delta+q \omega
$$

This expression equates the expected real return to lending to the real cost of borrowing plus the marginal cost of producing a loan. The term $q \omega$ reflects the fact that the bank pays bankruptcy costs, proportional to its total lending, with probability $q .{ }^{14}$

We conclude this subsection by noting that Proposition 2 implies that as long as banks have access to forward markets, they are indifferent between lending in local currency and lending in dollars. Given government guarantees it is optimal for banks to expose themselves to currency risk. When they borrow in dollars and lend in local currency, currency risk

\footnotetext{
${ }^{14}$ In the case of government guarantees we need to assume that $R \leq \delta / q+\omega$ to rule out covered interest arbitrage. A firm can borrow one unit of local currency at rate $R^{a}$, convert it into $1 / S^{I}$ dollars, invest them at the world interest rate $R$, and sell the proceeds in the forward market. This operation will fail to yield a risk-free profit if: $R^{a} \geq F R / S^{I}$. Under guarantees equation (2.14) implies that the no-arbitrage condition is satisfied if $R \leq \delta / q+\omega$. Under no guarantees equation (2.11) implies that $R^{a}>F R / S^{I}$ always holds.
} 
arises naturally. However, even when banks borrow and lend in dollars, they can still take on currency risk by selling dollars forward. By making $x$ sufficiently negative banks can drive their residual value in the devaluation state, net of bankruptcy costs, to zero and their expected cost of borrowing to $(1-q) R L+q \omega L$. But this coincides with the expected cost of borrowing for a bank that borrows in dollars and lends in local currency. It follows that banks are indifferent between lending in dollars and lending in local currency. If a bank cannot sell dollars forward when it is lending in dollars, our analysis implies that banks actually prefer to lend in local currency.

\subsection{Extensions: Fractional Bailouts, Capital Requirements and Reputation}

The analysis so far abstracts from various issues that may be important in practice. In this subsections we consider three such issues-fractional bailouts, capital requirements and reputation effects-and see how they impact on our results.

1. Imperfect Guarantees So far we have abstracted from uncertainty or incompleteness of government guarantees. In a model similar to ours, Burnside, Eichenbaum and Rebelo (2001) consider the case where there are probabilistic or, equivalently, fractional bailouts. They show that the lower is the probability of a bailout the lower the likelihood that banks will not fully hedge their currency risk. A similar result obtains here. To see this we sketch the proof focusing on the natural case where banks contemplate defaulting only when a devaluation occurs.

Suppose that the government will repay bank's foreign creditors with probability $\alpha$ in the event of a devaluation. The value of $R^{b}$ such that foreign creditors receive expected returns of $R L$ is:

$$
R L=(1-q) \times R^{b} L+q \alpha \times R L
$$

This implies that:

$$
R^{b}=R \frac{(1-q \alpha)}{1-q}
$$

Consider a bank that decided to default in the devaluation state. Its optimal strategy continues to be to choose $x$ to minimize $\operatorname{ECB}(x, L)$. This requires setting $x$ so that the residual value of the bank when default occurs is equal to the bankruptcy costs: $V^{R}\left(S^{D}\right)=$ $\omega L$. Under this strategy the expected cost of borrowing is given by:

$$
E C B(x, L)=(1-q) R^{b} L+q V^{R}\left(S^{D}\right)
$$




$$
\begin{aligned}
& =R(1-q \alpha) L+q V^{R}\left(S^{D}\right), \\
& =R(1-q \alpha) L+q \omega L .
\end{aligned}
$$

Under full hedging the bank's $E C B$ is given by $R L$. This implies that full hedging is not optimal as long as:

$$
\omega<R \alpha
$$

In the case of perfect guarantees $(\alpha=1)$ we recover the condition discussed in our proposition 2: $\omega<R$.

2. The Role of Net Worth It is often the case that owners of banks are required to contribute some of their own capital to finance ongoing loan operations. This capital can be though of as the 'net worth' on the liabilities side of a bank's balance sheet. We now discuss one way to incorporate net worth considerations into the model and see how it impacts on our conclusions. ${ }^{15}$

Up to now we have abstracted from these net worth considerations. One might naturally expect that net worth would create an incentive for banks to hedge exchange rate risk. As it turns out, whether this is true or not in our environment depends is a subtle way on the interaction between bankruptcy costs and net worth. We consider two cases. In the first case banks use their own capital to finance a fraction $\mu$ of their loans. If they default bankruptcy costs are proportional to the size of their loan portfolio. This implies that a proportion $\omega$ of the bank's capital is dissipated by bankruptcy per se. In this case net worth considerations increase the likelihood that banks will hedge their exchange rate risk. In the second case banks post a bond whose real value $\mu L$ is proportional to their total loans. If the bank goes bankrupt the real value of that bond is unaffected. In this case net worth considerations do not impact on banks' decisions to hedge their exchange rate risk.

We now discuss these two possibilities, focusing on the natural case where banks contemplate default in the devaluation state.

Suppose that banks have to finance a fraction $\mu$ of outstanding loans from their own capital. This means that if the bank lends $L$ units of output it only needs to borrow $(1-\mu) L$ from the international capital market. This means that the net worth of the bank is $\mu L$.

\footnotetext{
${ }^{15}$ There is an extensive theoretical and empirical literature on the importance of not worth constraints on firm behavior. For a recent review of this literature see Gilchrist, Bernanke and Gertler (1999).
} 
Under guarantees, $R^{b}=R$ and the expected cost of borrowing would be given by:

$$
E C B(x, L)=(1-q)(1-\mu) R L+q V^{R}\left(S^{D}\right) .
$$

The residual value of the bank is given by:

$$
V^{R}(S)=\frac{R^{a} S^{I} L}{S}-\delta L+x\left(\frac{1}{F}-\frac{1}{S}\right),
$$

while the no default condition on forward contracts remains:

$$
\frac{R^{a} S^{I} L}{S}-\delta L+x\left(\frac{1}{F}-\frac{1}{S}\right) \geq \omega L .
$$

Banks continue to choose a lower value of $x$ to ensure that their residual value is $\omega L$. It is optimal for banks to go bankrupt when a devaluation occurs whenever the expected cost of borrowing is lower than $(1-\mu) R L$, which is the expected cost of borrowing with full hedging:

$$
(1-q)(1-\mu) R L+q \omega L<(1-\mu) R L
$$

This is true whenever:

$$
\omega<(1-\mu) R \text {. }
$$

In this case the presence of net worth considerations, i.e. $\mu>0$, reduce the range of circumstances under which banks will not hedge under government guarantees. In the limit where banks are completely self financed $(\mu=1)$ they will fully hedge exchange rate risk even in the presence of government guarantees.

Consider now the case where banks post a bond whose real value $\mu L$ is proportional to the size of their loan portfolio. We assume that the bank earns a gross interest rate $R$ on the bond. Under guarantees the expected cost of borrowing is given by:

$$
\operatorname{ECB}(x, L)=(1-q) R L+q V^{R}\left(S^{D}\right) .
$$

The residual value of the bank, which now includes the end of period value of the posted bond, $R \mu L$, is:

$$
V^{R}(S)=\frac{R^{a} S^{I} L}{S}-\delta L+x\left(\frac{1}{F}-\frac{1}{S}\right)+R \mu L,
$$

The no-default condition on forward contracts is given by:

$$
\frac{R^{a} S^{I} L}{S}-\delta L+x\left(\frac{1}{F}-\frac{1}{S}\right)+R \mu L \geq \omega L .
$$


Banks choose a lower value of $x$ to ensure that their residual value is $\omega L$. It is optimal for banks to go bankrupt when a devaluation occurs whenever the expected cost of borrowing is lower than $R L$, which is the expected cost of borrowing with full hedging:

$$
(1-q) R L+q \omega L<R L
$$

This is true whenever:

$$
\omega<R .
$$

This is of course, the same condition that we obtained when we abstracted entirely from net worth considerations.

We conclude that whether net worth considerations affect the likelihood of default depends crucially on whether bankruptcy costs apply to the particular assets where net worth is embedded.

3. Reputation Effects In our analysis we abstracted from reputation effects. It might be thought that these effects would lead banks to expose themselves to less currency risk. A simple way to make the point concretely is to assume that when a bank defaults there is a loss of reputation whose real value is given by $\rho L$. Under guarantees $R^{b}=R$ and the expected cost of borrowing would be given by:

$$
\begin{aligned}
\operatorname{ECB}(x, L) & =(1-q) R^{b} L+q\left(V^{R}\left(S^{D}\right)+\rho L\right) \\
& =(1-q) R L+q(\omega L+\rho L)
\end{aligned}
$$

It follows that it is optimal to declare bankruptcy when a devaluation occurs if:

$$
R>\omega+\rho .
$$

A larger value for $\rho$, i.e. a bigger loss in reputation, decreases the likelihood that banks would choose to declare bankruptcy. In practice it is very difficult to assess how large $\rho$ is. This is particularly true in our context. Here the the crisis is systemic-all banks declare bankruptcy when a devaluation occurs and no foreign lenders suffer. Under these circumstances, it is not clear that the reputation of any individual banker is affected by default.

\subsection{The Firm's Problem}

Output, $y$, is produced by perfectly competitive firms which use labor, $h$, according to the technology $y=A h$. Firms pay the real wage rate, $w$, which is set at the beginning of the 
period, prior to the realization of the exchange rate. Wage payments are in units of the local currency. ${ }^{16}$ Firms must borrow their wage bill from the banks at the gross interest rate $R^{a}$, so their expected profits are given by $A h-R^{a} w h$. The first order condition for $h$ is:

$$
w=A / R^{a}
$$

\subsection{The Household Problem}

The representative household inelastically supplies one unit of labor in each period and maximizes expected lifetime utility, which depends on consumption, $c_{t}$, and real balances, $M_{t} / S_{t}$ :

$$
U=E_{0} \sum_{t=0}^{\infty} \beta^{t}\left[\log c_{t}+\phi \log \left(M_{t} / S_{t}\right)\right], \quad 0<\beta<1 .
$$

To abstract from trends in the economy's current account we assume that $\beta$ equals $R^{-1}$. The sequential budget constraint faced by the household depends on the time period under consideration. During floating exchange rate periods $(t>T)$ it is given by:

$$
a_{t+1}=R a_{t}+w_{t}+\pi_{t}-\tau_{t}-c_{t}-\left(M_{t+1}-M_{t}\right) / S_{t}
$$

The variable $a_{t}$ represents beginning of period $t$ net foreign assets, $w_{t}$ is real labor income, $\tau_{t}$ represents lump-sum taxes, and $\pi_{t}$ are the firm's profits. ${ }^{17}$ The variable $M_{t}$ represents the stock of local currency held by the households in the beginning of period $t$. Notice that we have abstracted from the fact that households can hold demand deposits in domestic banks. In Section 5 we show that our basic results go through in a version of the model that incorporates these deposits.

In the devaluation period $(t=T)$ the household's sequential budget constraint is given by:

$$
\begin{gathered}
a_{T+1}=R a_{T}+w_{T}+\pi_{T}-\tau_{T}-c_{T}-\frac{M_{T+1}-M^{D}}{S^{D}}+\chi+x_{T}^{h}\left(\frac{1}{F}-\frac{1}{S^{D}}\right) \\
M^{D}=M_{T}-\chi S^{I}
\end{gathered}
$$

Recall that $\chi$ is the amount of reserves that the central bank is willing to lose before a devaluation. At the time of the devaluation the household redeems $\chi S^{I}$ units of local currency

\footnotetext{
${ }^{16}$ Firms must hedge against the risk of a devaluation to ensure that they can pay the agreed upon real wage rate. The details of the required hedging strategy are discussed in the Appendix.

${ }^{17}$ We ignore bank's profits since these are always zero in equilibrium.
} 
in exchange for foreign reserves. This is why its initial money holdings in (2.18) equal $M^{D}$, defined in (2.19), and the term $\chi$ appears as an asset. The variable $x_{T}^{h}$ denotes the number of units of local currency sold by the household in the forward market in the previous period. The household has an incentive to enter these contracts during the fixed exchange rate regime. By entering the forward market it can insure against the effect of a devaluation on the value of its real balances. We will see later that allowing households to hedge implies that consumption is constant over time. This greatly simplifies the analysis, enabling us to characterize analytically the equilibrium of the economy.

During the fixed exchange regime $(t<T)$ the budget constraint is:

$$
a_{t+1}=R a_{t}+w_{t}+\pi_{t}-\tau_{t}-c_{t}-\frac{M_{t+1}-M_{t}}{S^{I}}+x_{t}^{h}\left(\frac{1}{F}-\frac{1}{S^{I}}\right),
$$

where $a_{0}$ and $M_{0}$ are given.

Finally we impose the no-Ponzi game condition: $E_{0} \lim _{t \rightarrow \infty} a_{t+1} / R^{t}=0$.

\subsection{The Government}

During the fixed exchange rate regime $(t<T)$ the government's flow budget constraint is:

$$
f_{t+1}=R f_{t}+\left(M_{t+1}^{S}-M_{t}^{S}\right) / S^{I}+\tau_{t}-g_{t}
$$

Here $f_{t}$ denotes the government's net foreign assets at the beginning of the time period, $g_{t}$ is the level of real government purchases and $M_{t}^{S}$ denotes the endogenous level of the money supply that is consistent with a fixed exchange rate regime at time $t$. Not surprisingly, $M_{t}^{S}$ turns out to be constant for $t<T$.

The government's flow budget constraint during the devaluation period $(t=T)$ is:

$$
f_{T+1}=R f_{T}-\chi-\Gamma+\left(M_{T+1}^{S}-M^{D}\right) / S^{D}+\tau_{T}-g_{T}
$$

Here, $\Gamma$ represents the cost of honoring guarantees to bank's foreign creditors. From Proposition 2 we know that $\Gamma$ equals $R L$. To simplify, we assume that the government repays $\Gamma$ in the devaluation period $T$.

During the floating exchange rate period $(t>T)$ the government's flow budget constraint is:

$$
f_{t+1}=R f_{t}+\left(M_{t+1}^{S}-M_{t}^{S}\right) / S_{t}+\tau_{t}-g_{t}
$$

We impose the condition:

$$
E_{0} \lim _{t \rightarrow \infty} f_{t+1} / R^{t}=0
$$


We assume that $g_{t}=g$ for all $t, \tau_{t}=\tau$ for all $t \neq T$ and that $f_{t}=f_{0}$ for $t<T$. Once the fixed exchange rate is abandoned, there is no uncertainty in the economy. These assumptions fact together with equations (2.22), (2.23) and (2.24) imply that at time $T$ the government's intertemporal budget constraint is:

$$
\Gamma+\chi=\frac{M_{T+1}^{S}-M^{D}}{S^{D}}+\sum_{j=1}^{\infty} \frac{1}{R^{j}}\left(\frac{M_{T+j+1}^{S}-M_{T+j}^{S}}{S_{T+j}}\right)+\tau_{T}-\tau .
$$

This equation simply says that seigniorage revenues must equal the value of the bailout, $\Gamma$, plus the loss of reserves incurred during the attack plus any resources raised a fiscal reform at time $T$.

\subsection{The Competitive Equilibrium}

We conclude this section with a definition of the competitive equilibrium that applies to economies with and without government guarantees to foreign creditors.

Definition A competitive equilibrium for this economy is a set of stochastic processes for quantities $\left\{c_{t}, x_{t}, x_{t}^{h}, M_{t}, M_{t}^{S}, a_{t+1}, f_{t+1}, \Gamma, h_{t}, L_{t}\right\}$ and prices $\left\{w_{t}, R_{t}^{a}, R_{t}^{b}, P_{t}, S_{t}, F_{t}\right\}$ such that: (i) $c_{t}, x_{t}^{h}, M_{t+1}, a_{t+1}$ solve the household's problem given the stochastic process for prices;

(ii) the government's intertemporal budget constraint (2.21) - (2.25) holds; (iii) the money market clears with $M_{t}^{S}=M_{t}$; (iv) the loan market clears with $L_{t}=w_{t} h_{t}$; and (v) the labor market clears with $h_{t}=1$.

\section{A Sustainable Fixed Exchange Rate Regime}

In this section we demonstrate that there exists a sustainable equilibrium with a fixed exchange rate. The existence of this equilibrium follows from two basic assumptions: (i) agents assign probability zero to a devaluation, so that there is no uncertainty in the economy; (ii) the government does not require seigniorage revenues to satisfy its intertemporal budget constraint.

With no exchange rate uncertainty, banks can borrow from foreigners at the risk free rate, $R^{b}=R$. Absent the possibility of a devaluation, government guarantees are irrelevant, so that $\Gamma$ equals 0 . Also, hedging plays no role in the analysis, so $x_{t}=x_{t}^{h}=0$. Finally, the forward rate coincides with the spot rate $F=S^{I}$.

It follows from (2.11) that:

$$
R^{a}=R+\delta
$$


In addition, equation (2.15) implies that the market clearing real wage rate is given by:

$$
w=A /(R+\delta)
$$

This completes our description of equilibrium prices.

To determine the household's consumption and real balances we write its value function as:

$$
V\left(a_{t}, M_{t}\right)=\max _{c_{t}, a_{t+1}, M_{t+1}}\left\{\log c_{t}+\phi \log \left(M_{t} / S^{I}\right)+\beta V\left(a_{t+1}, M_{t+1}\right)\right\}
$$

subject to (2.17). The first order conditions for this problem are:

$$
\begin{aligned}
1 / c_{t} & =\beta\left(\frac{1}{c_{t+1}}+\frac{\phi}{M_{t+1} / S^{I}}\right), \\
1 / c_{t} & =\beta R / c_{t+1} .
\end{aligned}
$$

Our assumption that $\beta=R^{-1}$ implies that consumption and money holdings are constant over time. Using this fact, iterating on (2.17) and imposing the transversality condition $\left(\lim _{t \rightarrow \infty} \beta^{t} a_{t+1} / c_{t+1}=0\right)$, we obtain that net foreign assets are constant over time. In addition we find that:

$$
\begin{aligned}
c_{t} & =(R-1) a_{0}+w-\tau, \\
a_{t} & =a_{0}, \\
m_{t} & =M / S^{I}=\beta \phi c /(1-\beta) .
\end{aligned}
$$

Here we have used the fact that firms' profits are zero in equilibrium.

Since real balances are constant and the inflation rate is zero, the government collects no seigniorage revenues. Consequently, its intertemporal budget constraint is given by:

$$
(R-1) f_{0}=g-\tau
$$

By construction, this analysis demonstrates that there is a unique fixed exchange rate competitive equilibrium with $c_{t}, a_{t}$ and $M_{t}$ constant over time, given by (3.1)-(3.3). In addition $f_{t}$ is constant: $f_{t}=f_{0}$. This completes our description of equilibrium quantities.

Throughout the paper we assume that (3.4) holds, so that, in the absence of self-fulfilling speculative attacks, the fixed exchange rate regime is sustainable.

Combining the government and household budget constraints and using the fact that $c_{t}, a_{t}, f_{t}$ and $M_{t}$ are constant over time, we can express the economy's aggregate resource constraint as

$$
c+g=(R-1)\left(a_{0}+f_{0}\right)-A \frac{R+\delta-1}{R+\delta}+A .
$$


The first term on the right hand side is net interest on foreign assets. The second term is the real cost of intermediation. The latter reflects the physical costs of producing loans and the interest rate costs incurred because domestic banks borrow funds from abroad. ${ }^{18}$ Since employment is normalized to 1 , total output, the last term, is equal to $A$.

\section{Self-Fulfilling Currency Crises}

Can self-fulfilling speculative attacks occur in an economy with government guarantees? To answer this question we begin by assuming that such an attack can occur in equilibrium. We then construct candidate equilibrium price and quantity allocations for the three types of time periods in our model. By construction these allocations satisfy the optimization problems of the different agents in the model and the market clearing conditions. The key condition that must be verified is whether the exchange rate actually depreciates in the proposed equilibrium, i.e. $S^{D} / S^{I}>1$. Whether or not this is true depends on the nature of monetary and fiscal policy after the devaluation. Here we consider two cases. First, we analyze the 'no fiscal reform' case, in which the government finances the costs associated with a devaluation entirely via seigniorage revenues. For the sake of simplicity we confine ourselves to an endogenously determined constant growth rate of money. Proposition 3 establishes that, subject to a regularity condition, self-fulfilling speculative attacks can occur. Second, we analyze the 'fiscal reform' case. Here the government commits to expanding the growth rate of money at an exogenous rate $\gamma$ and adjusts lump sum taxes, $\tau_{T}$, to fulfill its intertemporal budget constraint. Proposition 4 provides conditions - on the quantity of reserves that the government is prepared to lose, the growth rate of money, and the size of the bailout - for which self-fulfilling attacks can occur.

We solve our model in three stages. First, we study the floating exchange rate regime. Then, we analyze the fixed exchange rate regime. Finally, we consider the devaluation period. Below we summarize the key features of the economy during the different time periods, assuming that a self-fulfilling speculative attack will occur.

Throughout our discussion we use the fact, proved in the Technical Appendix, that

\footnotetext{
${ }^{18}$ Banks borrow $w=A /(R+\delta)$ dollars abroad. They use $\delta A /(R+\delta)$ units of output to produce these loans. At the end of the period they repay foreigners at a net cost of $(R-1) A /(R+\delta)$. Thus, the total cost of intermediation is $(R+\delta-1) A /(R+\delta)$.
} 
consumption, $c_{t}$, and the household's real assets $a_{t}$ are constant for all $t:^{19}$

$$
c=(R-1)\left(a_{0}+f_{0}\right)-g+\frac{(R-1) w^{I}+q w^{F}-q(R-1) \Gamma}{R-1+q} .
$$

Here $w^{I}$ denotes the real wage rate during the fixed exchange rate period and the period in which the devaluation occurs, while $w^{F}$ denotes the real wage rate during the floating exchange rate period. The fact that $c_{t}$ and $a_{t}$ are constant hinges on our assumption that under the fixed exchange rate regime households hedge exchange rate risk through forward contracts. According to (4.1), consumption is equal to the household's permanent income, where the latter is defined to take account of the annuitized expected present value of the bank bailout, $q(R-1) \Gamma /(R-1+q)$.

\subsection{The Floating Exchange Rate Regime $(t \geq T+1)$}

With no exchange rate uncertainty, banks can borrow from foreigners at the risk free rate, $R^{b}=R$. The presence of guarantees is irrelevant and hedging plays no role in the analysis, so $x_{t}=x_{t}^{h}=0$. Firms earn zero profits in each period. Finally, the forward rate coincides with the future spot rate, so $F_{t}=S_{t+1}$ and $F_{t} / S_{t}=\gamma$. The law of motion for the exchange rate and the money supply are:

$$
\begin{aligned}
S_{t} & =S^{D} \gamma^{t-T}, t \geq T \\
M_{t} & =M^{D} \gamma^{t-T}, t \geq T
\end{aligned}
$$

Recall that $S^{D}$ is the exchange rate that prevails when the government abandons the fixed exchange rate in period $T$. The variable $M^{D}$ represents the level of the money supply after the speculative attack.

The banks' first order condition for $L$ during the floating exchange rate regime implies:

$$
R^{a}=\gamma(R+\delta)
$$

while equation (2.15) implies that the market clearing real wage rate is given by $w^{F}=$ $A /[\gamma(R+\delta)]$.

During the floating exchange rate regime expected inflation is constant and equal to $\gamma-1$. The demand for real balances is given by:

$$
m^{F}=M_{t} / S_{t}=\phi c /(\gamma / \beta-1)
$$

\footnotetext{
${ }^{19}$ The Technical Appendix is available upon request.
} 
Relation (4.4) implies that real balances are a decreasing function of the nominal interest rate since the latter equals $\gamma / \beta-1$ during the flexible exchange rate regime.

\subsection{The Fixed Exchange Rate Regime $(t<T)$}

At any time period $t<T$ there is exchange rate uncertainty, since a devaluation may occur next period with probability $q$. In the presence of government guarantees banks behave as described in Proposition 2 and $R^{b}=R$. In addition, banks set $x_{t}$ to the lowest value consistent with (2.6). The exchange rate is equal to $S^{I}$ and the forward rate is given by (2.2). The time $t$ equilibrium interest rate at which banks lend to firms, given by (2.14), can be written as

$$
R^{a}=\frac{(1-q) R+\delta+q \omega}{E_{t}\left(P_{t} / P_{t+1}\right)}
$$

where $E_{t}\left(P_{t} / P_{t+1}\right)=(1-q)+q S^{I} / S^{D}$. The numerator of (4.5) reflects the fact that the bank only pays off its loans if there is no devaluation, a state that occurs with probability $(1-q)$. If we were to make the approximation (which we don't) that $1 / E_{t}\left(P_{t} / P_{t+1}\right) \cong E_{t}\left(P_{t+1} / P_{t}\right)$, then we would obtain a version of the Fisher equation for the nominal interest rate, $R_{a} \cong$ $E_{t}\left(P_{t+1} / P_{t}\right)[(1-q) R+\delta+q \omega]$.

Real wages are given by the firm's first order condition, (2.15):

$$
w^{I}=A / R^{a} .
$$

In the Technical Appendix we show that the solution to the household problem yields a constant value for $x_{t}^{h}$ which satisfies:

$$
w^{I}+\pi^{I}+x^{h}\left(\frac{1}{F}-\frac{1}{S^{I}}\right)=\left[w^{I}+\pi^{D}+x^{h}\left(\frac{1}{F}-\frac{1}{S^{D}}\right)\right] \frac{R-1}{R}-\frac{R-1}{R} \Gamma+\frac{1}{R} w^{F}
$$

The left hand side of (4.7) denotes the household's income in non-devaluation states. The term $x^{h}\left(1 / F-1 / S^{I}\right)$ is the loss associated with forward contracts in those states of the world. The first term on the right hand side is the annuity value of labor income, firm profits and forward contract profits in the devaluation period. The second term is the annuity value of the bailout. Finally, the third term is the constant wage rate in the floating exchange rate period (profits are equal to zero during the floating exchange rate regime). By choosing this value of $x^{h}$ the household can perfectly smooth consumption across all states of the world.

During the fixed exchange rate regime expected inflation is constant and equal to $q\left(S^{D} / S^{I}-\right.$ 1). In the Technical Appendix we show that households choose real balances so that

$$
m^{I}=\frac{\beta \phi c}{1-\beta+\beta q\left(1-S^{I} / S^{D}\right)} .
$$


Real balances are decreasing in expected inflation. During this regime the endogenous money supply must be consistent with the real balances demanded by households and the fixed exchange rate. Therefore $M_{t}^{S}=S^{I} m^{I}$ for all $t<T$.

\subsection{The Devaluation Period $(t=T)$}

At the beginning of period $T$, prior to the realization of the stochastic process signalling the onset of a devaluation, banks borrow from abroad and lend to domestic firms at the value of $R^{a}$ that prevails in the fixed exchange rate regime. Proposition 2 implies that, in an economy with government guarantees, once the currency is devalued the banks renege on their foreign debt and declare bankruptcy. Due to the banks' hedging strategy, their residual value, net of bankruptcy costs, is equal to zero. Thus the total realized liability of the government, $\Gamma$, is $R L$.

Since firms make their hiring decisions at the beginning of the period prior to the devaluation, the real wage is the same as in the fixed exchange rate regime and is given by (4.6).

Recall that households enter the period with $M_{T}=m^{I} S^{I}$ units of the local currency. Once the random variable signaling the onset of a devaluation is realized, agents redeem $\chi S^{I}$ units of local currency in exchange for foreign reserves. The exchange rate rises from $S^{I}$ to $S^{D}$, at which point agents are left holding $M^{D}=M_{T}-\chi S^{I}$ units of local currency. In the Technical Appendix we prove the following lemma which reflects our assumption that money grows at the rate $\gamma$ starting from the level $M^{D}$ (see equation 4.2).

Lemma The rate of inflation from the onset of the devaluation to the first period of the floating exchange rate regime $(T+1)$ is: $S_{T+1} / S^{D}=\gamma$. The level of real balances at the onset of the devaluation is:

$$
\frac{M^{D}}{S^{D}}=m^{F}=\frac{\phi c}{\gamma / \beta-1} .
$$

Integrating over the previous results we have constructed all of the endogenous variables in an equilibrium where a self-fulfilling currency attack occurs at the random date $T$ as a function of four unknowns: $\gamma, S^{D}, c$ and $m^{I}$. In the Technical Appendix we analyze the system of equations that determines these variables and verify whether $S^{D}$ exceeds $S^{I}$, i.e. whether a self-fulfilling currency attack actually occurs at $T$. 


\section{No Fiscal Reform}

We first consider the case in which there is no fiscal reform, i.e. the government finances all of the costs associated with a devaluation via seigniorage revenues.

Proposition 3 Suppose that in the event of a devaluation the government chooses $\gamma$ so that the present value of government liabilities after a devaluation, $\Gamma+\chi$, is fully financed by seigniorage. Then, as long as $\Gamma>0$ and $\Gamma+\chi$ is smaller, for some $q>0$, than the maximum present value of seigniorage, $\phi c_{S} /(R-1)$, a self-fulfilling speculative attack can occur. Here $c_{S}$ denotes the level of consumption in the sustainable fixed exchange rate equilibrium, defined in (3.5).

Proof: See the Technical Appendix.

The previous proposition implies that as long as there are government guarantees and it is feasible to finance the obligations associated with the devaluation via seigniorage, a selffulfilling speculative attack will almost surely occur. The intuition is that with government guarantees a devaluation transforms potential liabilities into actual liabilities. If forward looking agents believe that these liabilities are financed via seigniorage, they will reduce their domestic money holdings, exchanging them for foreign reserves. Given our assumptions this reduction triggers the government threshold rule for abandoning the fixed exchange rate regime. At this point, the currency depreciates and the banks declare bankruptcy. This forces the government to payoff foreign creditors. This, in turn, rationalizes the private agents' beliefs about monetary policy and inflation that generated the crisis.

Under the assumptions of Proposition 3, a crisis happens regardless of the reserves that the government is willing to spend in defense of the currency, $\chi$. The higher $\chi$ is, the higher are the government's losses during the speculative attack and the more seigniorage that needs to be collected after the fixed exchange rate regime is abandoned.

In the regularity condition, $\Gamma+\chi<\phi c_{S} /(R-1)$, the right hand side of this inequality equals the maximal present value of seigniorage that the government can extract from the economy. Using (4.4) and (4.9) it is straightforward to show that, for a given value of $\gamma$, the present value of seigniorage is given by $\phi c(\gamma-1) /[(\gamma-\beta)(R-1)]$. It follows that seigniorage is strictly increasing in the post-crisis inflation rate $\gamma$ with maximal value equal to $\phi c /(R-1)$ corresponding to $\gamma=\infty$. In the Technical Appendix we show that $c_{S}$ is an upper bound on the equilibrium value of $c$ that is attained in the limit, for arbitrarily small $q$; hence the upper bound on seigniorage is $\phi c_{S} /(R-1)$. In order for a self-fulfilling currency attack to occur 
in the 'no fiscal reform' case, it is necessary and sufficient that $\Gamma+\chi$ be smaller than the maximum present value of seigniorage. The reason this condition is necessary is that agents are expecting that the costs associated with a devaluation, $\Gamma+\chi$, will be fully financed with seigniorage. Obviously, if this is not possible, such an expectation cannot be self-fulfilling.

\section{Fiscal Reform}

We now turn to the case in which the devaluation is accompanied by a fiscal reform. Specifically, we assume that the law of motion for money is given by (4.4) where $\gamma$ is now an exogenous parameter. Since the government's intertemporal budget constraint does not hold for an arbitrary $\gamma$, we suppose that a devaluation is followed by a fiscal reform in which lump sum taxes, $\tau_{T}=\tau+\tau^{D}$, are adjusted to ensure that the intertemporal budget constraint, (2.25), holds. The following proposition characterizes the necessary and sufficient conditions for a self-fulfilling speculative attack to occur under these circumstances.

Proposition 4 Suppose that in the event of a devaluation the government finances the present value of government obligations associated with the devaluation, $\Gamma+\chi$, by choosing a fixed value of $\gamma$ and financing the remainder with post devaluation taxes, $\tau^{D}$. Then a self-fulfilling speculative attack can occur if:

$$
\chi \leq m_{S} \frac{\gamma-1}{\gamma-\beta}
$$

where $m_{S}$, defined in (3.3), is the level of real balances in the sustainable fixed exchange rate regime. The value of $\tau^{D}$ is given by:

$$
\tau^{D}=\chi+\Gamma-\phi c \frac{\beta}{\gamma-\beta} \frac{\gamma-1}{1-\beta} .
$$

Proof: See the Technical Appendix.

A standard view is that speculative attacks can be avoided if the government stands ready to buy back all outstanding real balances. This is true in our model only when $\gamma=\infty$, since it is only in this case that the post-crisis demand for real balances is zero. For finite rates of money growth, the demand for real balances remains positive and the government needs only to buy back a fraction $(\gamma-1) /(\gamma-\beta)$ of the real balances in a sustainable fixed exchange rate regime to avoid a self-fulfilling speculative attack. If the government can credibly commit to not using seigniorage revenues to finance an eventual bank bailout (i.e. it sets $\gamma$ to one), then self-fulfilling speculative attacks cannot occur. The next section elaborates on this point. 


\section{Allowing for Domestic Demand Deposits}

In this section we modify the benchmark model to allow banks to borrow from domestic households and issue demand deposits denominated in local currency. This modification allows us to address two shortcomings of the benchmark model. First, local currency borrowing is an important form of bank financing. By abstracting from this source of financing the benchmark model overstates the currency mismatch between banks' assets and liabilities. Second, the same monetary aggregate plays two different roles in the benchmark model: it enters both the government's intertemporal budget constraint and the household's problem. Since seigniorage revenue depends on the amount of currency that the government issues, high-powered money is the monetary aggregate that should enter the government's budget constraint. In contrast, household's utility presumably depends on a high order monetary aggregate, which includes the service flow from demand deposits. By explicitly incorporating demand deposits in the analysis we can deal with these two shortcomings and show that our basic results continue to hold.

\subsection{The Extended Model}

Our basic set up is similar to that considered in Chari, Christiano and Eichenbaum (1996) and Edwards and Vegh (1997). At the beginning of each period households hold all the currency in the economy, $M_{t}$. They deposit this currency in banks in return for demand deposits, $D_{t}^{h}$, that are denominated in local currency and yield an interest rate $R_{t}^{d}$. Since household's demand deposits are traded one-for-one for high powered money, we have:

$$
M_{t}=D_{t}^{h}
$$

The household's utility function is given by:

$$
U=E_{0} \sum_{t=0}^{\infty} \beta^{t}\left[\log c_{t}+\phi \log \left(D_{t}^{h} / S_{t}\right)\right], \quad 0<\beta<1 .
$$

Notice that utility now depends on the level of real demand deposits rather than on $M_{t} / S_{t}$. The household's sequential budget constraints are:

$$
\begin{gathered}
a_{t+1}=R a_{t}+w_{t}+\pi_{t}-\tau_{t}-c_{t}-\frac{D_{t+1}^{h}-R_{t}^{d} D_{t}^{h}}{S^{I}}+x_{t}^{h}\left(\frac{1}{F}-\frac{1}{S^{I}}\right), \quad t<T \\
a_{T+1}=R a_{T}+w_{T}+\pi_{T}-\tau_{T}-c_{T}-\frac{D_{T+1}^{h}-R_{T}^{d} D_{T}^{h}}{S^{D}}+\chi\left(1-\frac{S^{I}}{S^{D}}\right)+x_{T}^{h}\left(\frac{1}{F}-\frac{1}{S^{D}}\right),
\end{gathered}
$$




$$
a_{t+1}=R a_{t}+w_{t}+\pi_{t}-\tau_{t}-c_{t}-\frac{D_{t+1}^{h}-R_{t}^{d} D_{t}^{h}}{S_{t}}, \quad t>T
$$

Firms

Firms borrow $d$ units of local currency to finance their wage bill. Since wages are only paid at the end of the period and banks pay interest on the deposits of the firms, the effective interest rate on these loans is $R^{a}-R^{d}$. So the firm's end of the period liability from these loans is $\left(R^{a}-R^{d}\right) d / S$.

\section{Banks}

Banks have two sources of finance. First, they borrow $D_{t}^{h}=M_{t}$ units of local currency from households at an interest rate $R_{t}^{d}$. Second, they borrow $D_{t}^{*}$ dollars from abroad, at the interest rate $R_{t}^{b}$. They convert these dollars at the central bank into local currency at the beginning-of-period exchange rate, $S_{t-1}$. So banks' total reserves are $M_{t}+S_{t-1} D_{t}^{*}$. The government pays no interest on these reserves.

As in the benchmark model banks make loans denominated in local currency to firms at an interest rate $R_{t}^{a}$. In the act of making these loans, bank deposits of an equal value are created. These deposits pay an interest rate $R_{t}^{d}$. As before, the real cost of creating $L_{t}$ dollars worth of loans is $\delta L_{t}$.

The government imposes a reserve requirement on banks, such that banks must keep a fraction $\xi$ of their total liabilities in the form of high powered money. Since reserves do not pay interest this reserve requirement always holds with equality:

$$
\left(D_{t}^{h}+S_{t-1} L_{t}\right) \xi=M_{t}+S_{t-1} D_{t}^{*}
$$

Here $D_{t}^{h}+S_{t-1} L_{t}$ represents total bank deposits. The reserve requirement is assumed to hold at the moment when the banks make the loans to the firm. ${ }^{20}$

At the end of the period, when the exchange rate $S_{t}$ is determined, the bank's real profits are:

$$
\pi_{t}^{L}=\frac{R_{t}^{a} S_{t-1} L_{t}}{S_{t}}-\delta L_{t}+\frac{M_{t}+S_{t-1} D_{t}^{*}}{S_{t}}-R_{t}^{d} \frac{D_{t}^{h}+S_{t-1} L_{t}}{S_{t}}-R_{t}^{b} D_{t}^{*} .
$$

As in our baseline model, banks also have hedging profits of:

$$
\pi_{t}^{H}=x_{t}\left(\frac{1}{F_{t}}-\frac{1}{S_{t}}\right) \text {. }
$$

\footnotetext{
${ }^{20}$ Given our assumptions, the monetary base is $M_{t}+S^{I} D_{t}^{*}$ while $M 1$ is given by: $D_{t}^{h}+S^{I} L_{t}=\left(M_{t}+\right.$ $\left.S^{I} D_{t}^{*}\right) / \xi$.
} 
As before, a bank will default when $\pi_{t}=\pi_{t}^{L}+\pi_{t}^{H}<0$. We define the bank's residual value as:

$$
V_{t}^{R}=\pi_{t}+R_{t}^{b} D_{t}^{*}
$$

We assume, as before, that in bankruptcy states, the residual value of the bank must be sufficient to cover bankruptcy costs, $\omega L_{t}{ }^{21}$ Subject to this restriction and (5.2), banks will choose $L_{t}$ and $x_{t}$ to maximize:

$$
\begin{aligned}
V_{t} & =E\left(\max \left\{\pi_{t}, 0\right\}\right)=E\left(\max \left\{V_{t}^{R}-R_{t}^{b} D_{t}^{*}, 0\right\}\right) \\
& =E\left(V_{t}^{R}\right)-E\left(\min \left\{V_{t}^{R}, R_{t}^{b} D_{t}^{*}\right\}\right) .
\end{aligned}
$$

Absent government guarantees, $R^{b}$ is determined by the condition that the expected return to international creditors equals $R$ :

$$
R D^{*}=\operatorname{Pr}(\text { no default }) \times R^{b} D^{*}+\operatorname{Pr}(\text { default }) \times\left(V^{R}-\omega D^{*}\right)
$$

In the presence of government guarantees $R^{b}$ is given by:

$$
\begin{gathered}
R D^{*}=\operatorname{Pr}(\text { no default }) \times R^{b} D^{*}+\operatorname{Pr}\left(\text { default when } S=S^{I}\right) \times\left(V^{R}-\omega L\right)+ \\
\operatorname{Pr}\left(\text { default when } S=S^{D}\right) \times \max \left\{V^{R}-\omega L, R L\right\}
\end{gathered}
$$

\subsection{Results}

In this subsection we describe the versions of Propositions 1-4 that are applicable to the extended model. Formal proofs are contained in an Technical Appendix available upon request. Proposition 1 goes through as stated in Section 2. The logic underlying this proposition is the same as before. In the absence of government guarantees, banks that plan to default will be charged a higher interest rate due to bankruptcy costs. Banks find it optimal to avoid these costs by fully hedging.

Proposition 2 also continues to hold. In the presence of government guarantees it is not optimal to hedge exchange rate risk whenever $\omega<R$ and it is optimal to default when a devaluation occurs. This is true despite the fact that banks can now borrow domestically. Holding hedging constant, this source of finance reduces the currency mismatch between bank's assets and liabilities. However, because banks have access to forward markets, they can still set their residual value, net of bankruptcy costs, to zero in the devaluation state. That it is optimal to do so reflects the presence of government guarantees.

\footnotetext{
${ }^{21}$ This implies that banks are always able to repay domestic depositors in full.
} 
Finally, Proposition 3 and 4 continue to hold. ${ }^{22}$ This results from two key features of the extended model. First, banks behavior, as summarized by Propositions 1 and 2 remains the same. Second, in the presence of reserve requirements, household's demand for deposits generates an indirect demand for currency. As we show in the Technical Appendix, the indirect demand for currency in the extended model is proportional to the demand for currency in the benchmark model.

We conclude that extending the benchmark model to allow for demand deposits in local currency remedies its shortcomings while preserving our basic results.

\section{Policy Implications}

How can a government eliminate self-fulfilling speculative attacks? The most obvious solution is to regulate and supervise banks' hedging behavior to ensure that banks hedge their currency risk. In practice assessing the banks' currency exposure in real time may be very difficult. This is particularly true in countries such as Korea where banks have significant offshore operations.

Another obvious way to eliminate the possibility of self-fulfilling speculative attacks is to eliminate government guarantees. ${ }^{23}$ We are hesitant to devote too much attention to this possibility because these guarantees presumably confer some benefits that we have not modeled.

Our model suggests five other possibilities for eliminating self-fulfilling speculative attacks: (i) obtain a high enough level of reserves, that in combination with a credible partial fiscal reform will allow the government to successfully fend off a speculative attack; (ii) impose a tax on purchases of foreign currency in the event that a speculative attack occurs, (iii) impose capital requirements; (iv) get someone else to pay for the bank bailouts, and (v) dollarization. We discuss each of these in turn using the benchmark model.

\section{Reserves and Fiscal Reforms}

An implication of Proposition 4 is that a self-fulfilling attack can be avoided if the government credibly commits to raising taxes by the amount $\tau_{D}$ and is willing to spend an amount

\footnotetext{
${ }^{22}$ Our proof of proposition 3 in the Technical Apppendix associated with this section uses the additional regularity condition that the amount of foreign borrowing by banks $\left(D^{*}\right)$ in a sustainable fixed exchange rate regime is positive.

${ }^{23}$ See proposition 5 in the technical appendix which is available upon request.
} 
of reserves that exceeds $m_{S}(\gamma-1) /(\gamma-\beta)$. This formalizes a point stressed by Feldstein (1999) and others: having access and being able to use reserves to fend off a speculative attack, can eliminate the possibility of attacks. However, committing reserves is useful only if the government is also committed to an associated fiscal reform. In the limit, if the government can somehow credibly commit to completely paying its post devaluation liabilities with a fiscal reform, then the level of reserves is actually irrelevant. Under these circumstances, $\gamma=1$, the right hand side of (4.10) is zero and any positive amount of reserves forecloses the possibility of a self-fulfilling speculative attack.

\section{Tobin Taxes}

Recall that agents in our model coordinate on a signal that takes on the value one (which is associated with a devaluation) with probability $q$. Suppose that there are government guarantees but the government is not committed to a fiscal reform of the type described in Proposition 4. Instead, the government commits to taxing foreign exchange transactions at the rate $\theta$. So, if a successful attack occurs, the government will obtain tax revenues of $\theta \chi$. This revenue, together with seigniorage revenues, must totally finance the liabilities associated with a devaluation.

This simple Tobin tax has two effects. First, it alleviates the need to use seigniorage revenues to finance the liabilities associated with a devaluation. In the case where these revenues can finance the entire bank bailout $(\theta \chi \geq \Gamma)$, the Tobin tax amounts to a fiscal reform of such magnitude that seigniorage revenues are not required to finance the costs associated with a devaluation. Thus, a devaluation does not occur. ${ }^{24}$ We view this condition as unlikely to ever hold in practice, since it would require either huge values of $\chi$ or prohibitive values for $\theta$.

Second, the Tobin tax affects the incentives of private agents to trade local currency for foreign reserves. The after-tax profit to a private agent from converting a unit of local currency into reserves in the devaluation period is $\left(1-\theta-S^{I} / S^{D}\right)$. Obviously, if $\theta$ is such that $1-\theta-S^{I} / S^{D}<0$ agents will not attack the currency. The actual value of $\theta$ required to rule out a speculative attack depends on all the determinants of $S^{D}$, such as $\gamma$. For every $\gamma$ there exists an $S^{D}$, and therefore a $\theta$, that would rule out the attack. So in principle such a tax could be used to eliminate self-fulfilling speculative attacks. But one obvious problem

\footnotetext{
${ }^{24}$ See the introduction to the proofs of Propositions 3-5 in the Technical Appendix.
} 
with the tax is its state-contingent nature. Just what signal does the government need to credibly observe in order to trigger the tax?

\section{Net Worth or Capital Requirements}

In section 2 we showed that the impact of net worth consideration on the likelihood that banks hedge exchange rate risk in the presence of government guarantees depends sensitively on the nature of the assets within which net worth is embedded. In the first case, where bankruptcy costs do not apply to these assets, capital requirements are infective. They simply encourage banks to take more aggressive positions in forward markets. In the second case, where bankruptcy costs apply to these assets, capital requirements can be very effective. In particular, it is enough for the government to impose the legal requirement that $\mu$, the fraction of total loans financed with net worth, be larger than $(R-\omega) / R$ to ensure that banks hedge their currency risk. It is an open question which of these two cases is more empirically plausible.

\section{An External Bailout}

A different strategy for eliminating self-fulfilling speculative attacks is to gain access to an external entity that covers the costs of a bailout, $\Gamma$, if a speculative attack ever occurs. This guarantees that the government would not have to collect seigniorage revenues in the event of an attack, thus eliminating the possibility of an attack actually occurring. Since no attacks would happen in equilibrium the lender of last resort would never have to intervene. Even though this strategy works in the context of our model we are deeply skeptical about its real world applicability. In our model the only margin that banks can use to take advantage of the government's implicit guarantee is to expose themselves to exchange rate risk. In practice banks can exploit the presence of guarantees using other margins (e.g. investing in risky real estate ventures). In the presence of these additional margins a lender of last resort would create the moral hazard problems discussed by Calomiris (1998), Chari and Kehoe (1998), Mishkin (1999) and others.

\section{Dollarization}

Our model highlights a rationale for dollarization that is complementary to the analysis

in Calvo (1999). Governments offer guarantees to banks and their creditors for various 
reasons. $^{25}$ In a fixed exchange rate regime these guarantees lead to the possibility of selffulfilling currency crises. These crises cannot occur if guarantees are provided in a fully dollarized economy. This is because: (i) by its very nature, dollarization is a commitment mechanism to fund contingent liabilities to banks without recourse to seigniorage revenues; and (ii) dollarization guarantees the absence of a currency mismatch between banks' assets and liabilities.

\section{Conclusion}

This paper developed a theory of twin crises in which both fundamentals and self-fulfilling beliefs play an important role. The presence of government guarantees to banks' foreign creditors implies that a twin crisis can occur. The key channel by which guarantees lead to twin crises in our model is their affect on banks' willingness to expose themselves to currency risk. Absent government guarantees, self-fulfilling currency crises cannot occur. In this sense fundamentals matter. This makes us optimistic about the prospect of identifying countries in which crises will occur. However, the timing of the crises in our model depends subtly on agents' self-fulfilling beliefs about when the fixed exchange rate regime will collapse. This makes us pessimistic about the prospect of forecasting the precise time at which 'twin crises' will occur.

To streamline the model and focus on our main point we abstracted from the fact that output often declines after a crises. Allowing for such a decline would only strengthen our case. Suppose that a devaluation is associated with a decline in output which, in turn, causes a decline in tax revenues. Then the cost of the devaluation would be higher than the cost of bailing out the banks. This would make it easier for a self-fulfilling crisis to arise.

Finally, to simplify the model we assumed that the only inflation-related source of revenue for the government is printing money. Under these assumptions our model is likely to predict counterfactually high post-crisis inflation. In reality, governments can finance currency crisis related deficits using a variety of strategies. These include deflating the real value of outstanding nonindexed nominal debt and reducing the real value of government expenditures by deflating the real value of outlays that are fixed, at least temporarily, in nominal terms

\footnotetext{
${ }^{25}$ For example, guarantees might be welfare improving in the presence of financial market imperfections or the possibility of self-fulfilling bank runs. Burnside, Eichenbaum and Rebelo (2001) discuss a different reason why politicians might be tempted to provide guarantees. They argue that guarantees to banks' foreign creditors lower domestic interest rates and foster a boom in aggregate economic activity.
} 
(e.g. civil servant wages or social security payments). In addition, if non-tradable goods (e.g. expenditures on health and education) are an important component of government spending, then a decline in the dollar price of non-tradable goods automatically improves the government's fiscal situation. Burnside, Eichenbaum and Rebelo (2002) show that when a more realistic specification of the actual financing options open to a government are embedded in standard currency crisis models they can account for the low inflation rates that follow in the wake of many currency crises. It is important to emphasize that to gain access to these additional financing options the government must abandon the fixed exchange rate regime. So the central point in this paper is robust to allowing for a more realistic specification of the government budget constraint. 


\section{References}

Aghion, Philippe, Philippe Bacchetta, and Abhijit Banerjee (2001a) "Currency Crises and Monetary Policy in an Economy with Credit Constraints," European Economic Review, $45,1121-51$.

Aghion, Philippe, Philippe Bacchetta, and Abhijit Banerjee (2001b) "A Corporate BalanceSheet Approach to Currency Crises," mimeo, Harvard University.

Betker, Brian (1997) "The Administrative Costs of Debt Restructurings: Some Recent Evidence," Journal of Financial Management, 26, 56-68.

Burnside, Craig, Martin Eichenbaum and Sergio Rebelo (2001) "Hedging and Financial Fragility in Fixed Exchange Rate Regimes," European Economic Review, 45, 1151-93.

Calomiris, Charles (1998) "The IMF's Imprudent Role as Lender of Last Resort," The Cato Journal, 17, 275-94.

Burnside, Craig, Martin Eichenbaum and Sergio Rebelo (2002) "How Do Governments Pay for Fiscal Crises?," mimeo, Northwestern University.

Calvo, Guillermo (1999) “On Dollarization,” manuscript, University of Maryland.

Chang, Roberto and Andrés Velasco (2000a) "Financial Fragility and the Exchange Rate Regime," Journal of Economic Theory, 92, 1-34.

Chang, Roberto and Andrés Velasco (2000b) "Liquidity Crises in Emerging Markets: Theory and Policy," in Ben Bernanke and Julio Rotemberg, eds., NBER Macroeconomics Annual 1999. Cambridge, Mass.: MIT Press.

Chari, V.V. and Patrick Kehoe (1998) "Asking the Right Questions About the IMF," Federal Reserve Bank of Minneapolis Annual Report, Special Issue, 13, 2-26.

Chinn, Menzie and Kenneth Kletzer (2000) "International Capital Inflows, Domestic Financial Intermediation and Financial Crises under Imperfect Information," mimeo, University of California, Santa Cruz.

Cole, Harold and Timothy Kehoe (1996) "A Self-Fulfilling Model of Mexico's 1994-95 Debt Crisis," Journal of International Economics, 41, 309-30.

Corsetti, Giancarlo, Paolo Pesenti and Nouriel Roubini (1999) "Paper Tigers: A Model of the Asian Currency Crisis," European Economic Review, 43, 1211-36.

Demirgüç-Kunt, Asli and Enrica Detragiache (2000) "Does Deposit Insurance Increase Banking System Stability?" Working Paper WP/00/3, International Monetary Fund.

Diaz-Alejandro, Carlos (1985) "Good-Bye Financial Repression, Hello Financial Crash," Journal of Development Economics, 19, 1-24.

Dooley, Michael (2000) "A Model of Crises in Emerging Markets," The Economic Journal, $110,256-72$. 
Edwards, Sebastian and Carlos Vegh (1997) "Banks and Macroeconomic Disturbances under Predetermined Exchange Rates," Journal of Monetary Economics, 40, 239-278.

Eichengreen, Barry and Ricardo Hausmann (2000) "Exchange Rates and Financial Fragility," in Federal Reserve Bank of Kansas City, New Challenges for Monetary Policy.

Feldstein, Martin (1999) "A Self-Help Guide for Emerging Markets," Foreign Affairs, 78, 93-109.

Flood, Robert and Peter Garber (1984) "Collapsing Exchange Rate Regimes: Some Linear Examples," Journal of International Economics, 17, 1-13.

Gilchrist, Simon, Ben Bernanke and Mark Gertler "The Financial Accelerator in a Quantitative Business Cycle Framework," in John Taylor and Michael Woodford (eds.), the Handbook and Macroeconomics, Amsterdam: North Holland, 1999.

Jeanne, Olivier (1999) "Currency Crises: A Perspective on Recent Theoretical Developments," forthcoming in Princeton Studies in International Finance.

Kaminsky, Graciela and Carmen Reinhart (1999) "The Twin Crises: The Causes of Banking and Balance-of-Payments Problems," American Economic Review, 89, 473-500.

Kareken, John and Neil Wallace (1978) "Deposit Insurance and Bank Regulation: A Partial Equilibrium Exposition," Journal of Business, 51, 413-38.

Krugman, Paul (1979) "A Model of Balance of Payments Crises," Journal of Money, Credit and Banking, 11, 311-25.

Lahiri, Amartya and Carlos Vegh (1999) "Delaying the Inevitable: Optimal Interest Rate Policy and BOP Crises," mimeo, U.C.L.A.

McKinnon, Ronald and Huw Pill (1996) "Credible Liberalizations and International Capital Flows: The Overborrowing Syndrome," in T. Ito and A. Krueger, eds., Financial Deregulation and Integration in East Asia, 7-42. Chicago, Ill.: University of Chicago Press.

McKinnon, Ronald and Huw Pill (1998) "International Overborrowing: A Decomposition of Credit and Currency Risks," World Development, 26, 1267-82.

Mishkin, Frederic (1996) "Understanding Financial Crises: A Developing Country Perspective," in Michael Bruno and Boris Pleskovic, eds., Annual World Bank Conference on Development Economics 1996. Washington, DC: World Bank.

Mishkin, Frederic (1999) "Global Financial Instability: Framework, Events, Issues," Journal of Economic Perspectives, 13, 3-20.

Obstfeld, Maurice (1986) "Rational and Self-Fulfilling Balance-of-Payments Crises," American Economic Review, 76, 72-81.

Obstfeld, Maurice (1998) “The Global Capital Market: Benefactor or Menace?" Journal of Economic Perspectives, 12, 9-30. 
Schneider, Martin and Aaron Tornell (2000), "Balance Sheet Effects, Bailout Guarantees and Financial Crises," NBER Working Paper 8060.

Sercu, Piet and Raman Uppal (1995) International Financial Markets and the Firm. Cincinnati, Ohio: South-Western Publishing.

Velasco, Andrés (1987) "Financial Crises and Balance of Payments Crises: A Simple Model of the Southern Cone Experience," Journal of Development Economics, 27, 263-83. 


\section{A. Appendix}

\section{A.1. The Banking Sector}

We first establish that under the fixed exchange rate regime the objective function of the representative bank, (2.7), can always be rewritten as

$$
V(x, L)=E\left(V^{R}\right)(L)-E C B(x, L)=\left(\frac{S^{I}}{F} R^{a}-\delta\right) L-E C B(x, L) .
$$

Informally, $\operatorname{ECB}(x, L)$ is given by $(2.9)$. Formally, it is equal to

$$
\operatorname{ECB}(x, L)=\sum_{s \in\left\{S^{I}, S^{D}\right\}} \operatorname{Pr}(S=s) \min \left\{R^{b} L, V^{R}(s)\right\} .
$$

From $\left[(2.5) \downarrow\right.$ we get $\| V^{R}(S)=\pi(S)+R^{b}$ L. It follows that from $\langle(2.7)$ we bbtain

$$
V=(1-q) \max \left\{V^{R}\left(S^{I}\right)-R^{b} L, 0\right\}+q \max \left\{V^{R}\left(S^{D}\right)-R^{b} L, 0\right\} .
$$

Notice that $\max \left\{V^{R}(S)-R^{b} L, 0\right\}=V^{R}(S)-\min \left\{R^{b} L, V^{R}(S)\right\}$. So we have

$$
V=E\left(V^{R}\right)-(1-q) \min \left\{R^{b} L, V^{R}\left(S^{I}\right)\right\}-q \min \left\{R^{b} L, V^{R}\left(S^{D}\right)\right\} .
$$

In what follows it is convenient to divide the set of feasible $(x, L)$ pairs into 4 subsets:

1. $(x, L)$ pairs such that the bank is fully hedged, and never defaults,

2. $(x, L)$ pairs such that the bank defaults only when $S=S^{I}$,

3. $(x, L)$ pairs such that the bank defaults only when $S=S^{D}$, and

4. $(x, L)$ pairs such that the bank defaults in both states.

Proof of Proposition 1. We begin with the fact that (2.10) can be rewritten as

$$
R L=\sum_{s \in\left\{S^{I}, S^{D}\right\}} \operatorname{Pr}(S=s)\left\{\begin{array}{ll}
R^{b} L & \text { if } V^{R}(s) \geq R^{b} L \\
V^{R}(s)-\omega L & \text { otherwise }
\end{array}\right\}
$$

for strategies $1-3$, and $E\left(V^{R}\right)-\omega L \geq R L$, for strategy 4 . Hence

$$
E C B(x, L)=R L+\sum_{s \in\left\{S^{I}, S^{D}\right\}} \operatorname{Pr}(S=s)\left\{\begin{array}{ll}
0 & \text { if } V^{R}(s) \geq R^{b} L \\
\omega L & \text { otherwise }
\end{array}\right\}
$$

for strategies 1-3 and $E C B=E\left(V^{R}\right)$ for strategy 4. This implies that full-hedging, when feasible, strictly dominates strategies 2 and 3 , since $\omega L>0$. Full-hedging is feasible whenever $E\left(V^{R}\right) \geq R L$ or $R^{a} \geq\left(F / S^{I}\right)(R+\delta)$.

Suppose $R^{a}>\left(F / S^{I}\right)(R+\delta)$. This implies that full-hedging is feasible but also that banks could make infinite profits by lending infinite amounts.

On the other hand, if $R^{a}<\left(F / S^{I}\right)(R+\delta)$ then $E\left(V^{R}\right)<R L$ so that full-hedging and strategy 4 are not feasible. Strategies 2 and 3 imply $V<0$. 
This implies that the only possible equilibrium interest rate is $R^{a}=\left(F / S^{I}\right)(R+\delta)$. In this case full hedging is feasible at $x=F(R+\delta) L$ and $E\left(V^{R}\right)=R L$, implying $V=0$. As stated above, since full-hedging is feasible it strictly dominates strategies 2 and 3 . Strategy 4 is not feasible since $E\left(V^{R}\right)=R L$.

Proof of Proposition 2. Under guarantees, if there is default when $S=S^{D}$, foreign creditors receive $\max \left\{V^{R}\left(S^{D}\right)-\omega L, R L\right\}$. Hence, for strategies $1-3$, the condition determining a bank's borrowing rate when there are guarantees can be formally written as

$$
\begin{aligned}
R L=(1-q) & \times\left\{\begin{array}{ll}
R^{b} L & \text { if } V^{R}\left(S^{I}\right) \geq R^{b} L \\
V^{R}\left(S^{I}\right)-\omega L & \text { otherwise }
\end{array}\right\}+ \\
q & \times\left\{\begin{array}{ll}
R^{b} L & \text { if } V^{R}\left(S^{D}\right) \geq R^{b} L \\
\max \left\{V^{R}\left(S^{D}\right)-\omega L, R L\right\} & \text { otherwise }
\end{array}\right\} .
\end{aligned}
$$

A bank following strategy 4 faces the constraint that $(1-q)\left[V^{R}\left(S^{I}\right)-\omega L\right]+q \max \left\{V^{R}\left(S^{D}\right)\right.$ $-\omega L, R L\} \geq R L$. It follows that

1. full-hedging implies that $R^{b}=R$ and $E C B=R L$,

2. strategy 2 implies that $R L=(1-q)\left[V^{R}\left(S^{I}\right)-\omega L\right]+q R^{b} L$ and $E C B=R L+(1-q) \omega L$,

3. strategy 3 implies that $R^{b}=R$ and $E C B=(1-q) R L+q V^{R}\left(S^{D}\right),{ }^{26}$ and

4. strategy 4 implies that $E C B=E\left(V^{R}\right)$.

First, consider the possibility that the equilibrium interest rate is such that $R^{a}>$ $\left(F / S^{I}\right)[(1-q) R+\delta+q \omega]$. It is easy to establish that in this case, banks using strategy 3 would be able to make infinite profits by lending infinite amounts.

Next, consider the possibility that the equilibrium interest rate is such that $R^{a}<$ $\left(F / S^{I}\right)[(1-q) R+\delta+q \omega]$. In such circumstances, full-hedging and defaulting in both states are not feasible strategies. ${ }^{27}$ Even if feasible, strategies 2 and 3 imply $V<0$.

The only possible equilibrium interest rate is $R^{a}=\left(F / S^{I}\right)[(1-q) R+\delta+q \omega]$. This interest rate implies that $E\left(V^{R}\right)=[(1-q) R+q \omega] L<R L$, implying that full-hedging is not feasible. Furthermore, strategy 2 implies $V<0$. Strategy 4 is not feasible either. ${ }^{28}$ Conditional on strategy 3, to minimize its expected cost of borrowing, it is optimal for a bank to minimize $V^{R}\left(S^{D}\right)$ subject to the constraint that $V^{R}\left(S^{D}\right) \geq \omega L$. Since $\partial V^{R}\left(S^{D}\right) / \partial x>0$, the bank will choose the lowest $x$ consistent with $V^{R}\left(S^{D}\right) \geq \omega L, x=\left(\omega+\delta-R^{a} S^{I} / S^{D}\right) L /(1-q)\left(1 / S^{I}-\right.$ $\left.1 / S^{D}\right)$, implying $V^{R}\left(S^{D}\right)=\omega L, V^{R}\left(S^{I}\right)=R L, R^{b}=R, E C B=(1-q) R L+q \omega L$ and $V=0$.

\footnotetext{
${ }^{26}$ Notice that under strategy $3, V^{R}\left(S^{D}\right)<R L$, since otherwise we would have $V^{R}\left(S^{I}\right)>V^{R}\left(S^{D}\right) \geq R L$ implying that the bank was fully-hedged. Hence (A.2) implies $R^{b}=R$.

${ }^{27}$ Notice that the condition on $R^{a}$ implies that $E\left(V^{R}\right)<[(1-q) R+q \omega] L$. Hence, full-hedging is not feasible since $E\left(V^{R}\right)<R L$. For $V^{R}\left(S^{D}\right)-\omega L \geq R L$ the lending condition for strategy 4 can be written as $E\left(V^{R}\right)-\omega L \geq R L$, which contradicts $E\left(V^{R}\right)<R L$. For $V^{R}\left(S^{D}\right)-\omega L<R L$ the lending condition can be written as $V^{R}\left(S^{I}\right)-\omega L \geq R L$. Combining this with $V^{R}\left(S^{D}\right) \geq \omega L$ implies $E\left(V^{R}\right) \geq(1-q) R L+\omega L$, which is not true.

${ }^{28}$ The argument is the same as in the previous footnote.
} 


\section{A.2. Firms' Hedging Strategies}

Firm profits, in dollar terms, are given by

$$
\pi_{f}=A h-w h-\left(R^{a}-1\right) d / S+x_{f}(1 / F-1 / S)
$$

where $h$ is the firm's demand for labor, $w$ is the real wage rate, $d$ is the amount of local currency borrowed by the firm from the bank, and $x_{f}$ is the amount of local currency forward by the firm.

Firms maximize $E\left(\pi_{f}\right)=A h-w h-\left(R^{a}-1\right) d / F$ subject to the constraint that they have sufficient pesos on hand to pay their wage bill in advance: $S w h \leq d+S x_{f}(1 / F-1 / S)$, for all $S$. The two constraints imply that $d=x_{f}=F w h$. So $E\left(\pi_{f}\right)=A h-R^{a} w h$. The firm's first order condition for labor is $A=R^{a} w$. Realized profits are given by $\pi_{f}=A h(1-F / S)$ with $E\left(\pi_{f}\right)=0$. 